\title{
KAJIAN HIDRO-OSEANOGRAFI DI PERAIRAN KABUPATEN KARAWANG
}

\section{HYDRO-OCEANOGRAPHIC STUDY AT THE COASTAL AREAS OF KARAWANG DISTRICT}

\author{
Firman Agus ${ }^{1}$, Liliek Soeprijadi ${ }^{2 *}$, Roberto Pasaribu ${ }^{2}$ \\ ${ }^{1}$ Dinas Kelautan dan Perikanan Kab. Tangerang \\ ${ }^{2}$ Politeknik Kelautan dan Perikanan Karawang, Jalan Lingkar Tanjungpura, Karangpawitan, Kecamatan \\ Karawang Barat, Kabupaten Karawang, Jawa Barat 41315
}

Teregistrasi I tanggal: 07 Oktober 2019; Diterima setelah perbaikan tanggal: 06 Januari 2020; Disetujui terbit tanggal: 24 Januari 2020

\begin{abstract}
ABSTRAK
Pantai Karawang merupakan salah satu wilayah yang memiliki kesuburan perairan dan potensi sumber daya ikan yang cukup baik. Kondisi hidro-oseanografi yang meliputi arus laut, gelombang laut, dan pasang surut sampai saat ini belum dipublikasi. Penelitian ini bertujuan untuk mengamati kondisi hidro-oseanografi wilayah tersebut. Pengamatan kondisi hidro-oseanografi dilaksanakan pada bulan September 2017 di 3 kecamatan. Secara umum perairan kabupaten Karawang mempunyai kedalaman berkisar antara 0-20 meter. Pada bagian pinggir pantai mempunyai kedalaman antara 0-5 meter. Peta batimetri perairan kabupaten Karawang memperlihatkan morfologi yang berbentuk punggungan berselingan dengan cekungan kemiringan lereng yang relatif datar. Berdasarkan pengamatan dan hasil pengolahan data, parameter hidro-dinamika di perairan kabupaten Karawang memiliki tinggi gelombang laut antara 2,0-3,0 m dengan arah dari timur menuju Barat, kecepatan arus antara 0,125-0,167 m/detik dengan arah arus membentang dari Timur-Barat sedangkan rata-rata ketinggian pasang 0,446 $\mathrm{m}$ dan surut $0,349 \mathrm{~m}$.
\end{abstract}

Kata kunci: hidro oceanografi, arus, gelombang, pasang surut

\begin{abstract}
The coastal areas in Karawang district is one area that has good nursery ground and potential fish resources. Hydro-oceanographic conditions of the Karawang's coastal, including ocean currents, ocean waves, and tides, have not yet been published. This study aims to observe the hydrooceanographic conditions of the region. Observation of hydro-oceanographic conditions carried out in September 2017 in 3 sub-districts. In general, the coastal of Karawang district waters have a depth ranging from 0-20 meters. At the edge of the beach has a depth between 0-5 meters. Bathymetry map of Karawang district waters shows morphology in the form of ridges with relatively flat slope basins. Based on observations and results of data processing, the parameters of hydro-dynamics in the coastal of the Karawang district have a sea wave height between $2.0 \mathrm{~m}$ $3.0 \mathrm{~m}$ in the direction from east to West, current velocity between $0.125-0.167 \mathrm{~m} / \mathrm{sec}$ with the current direction stretching from East-West. In comparison, the average high tide is $0.446 \mathrm{~m}$, and low tide is $0.349 \mathrm{~m}$.
\end{abstract}

Keywords: hydro oceanography, ocean currents, ocean waves, tidal

\section{PENDAHULUAN}

Kabupaten Karawang mempunyai panjang pantai sekitar 84,32 $\mathrm{Km}$ yang membentang di sembilan wilayah kecamatan (Cilamaya Kulon, Cilamaya

Korespondensi penulis:
*Email: liliek.soeprijadi@gmail.com

DOI: http://dx.doi.org/10.15578/plgc.v1i1.8653 
Wetan, Tempuran, Pedes, Cilebar, Cibuaya, Tirtajaya, Batujaya, dan Pakisjaya). Laut teritorial kabupaten sesuai Undang- Undang Otonomi Daerah seluas 4 mil dari pasang surut terendah, dengan demikian dapat diketahui luas laut keseluruhan Kabupaten Karawang adalah \pm $621,27 \mathrm{Km}$ 2. Pantai Karawang termasuk ke dalam Pantai Utara yang memiliki kondisi topografi laut/batimetri yang relatif mendatar/landai. Secara umum perairan Kabupaten Karawang mempunyai kedalaman berkisar antara 0-20 meter. Pada bagian pinggir pantai mempuyai kedalaman antara 0-5 meter (Pemda Karawang, 2003).

Arus laut dapat juga terjadi akibat adanya perbedaan tekanan antara tempat yang satu dengan tempat yang lain. Perbedaan tekanan ini terjadi sebagai hasil adanya variasi densitas air laut dan slope permukaan laut. Densitas air laut bervariasi dengan suhu dan salinitas. Air tawar yang hangat adalah ringan, sementara air laut yang dingin adalah berat. Pada kedalaman yang besar (di bawah $2000 \mathrm{~m}$ ), densitas air laut hampir uniform (konstan) jadi variasi densitas umumnya terbatas pada lapisan dekat dengan permukaan. Perairan yang densitasnya rendah (hangat) mempunyai permukaan laut yang lebih tinggi daripada perairan yang densitasnya tinggi (dingin) akibatnya terdapat slope (kemiringan) permukaan laut antara daerah densitas rendah dan tinggi (Aziz, 2006).

Gelombang laut pada umumnya timbul oleh pengaruh angin, walaupun masih ada faktor-faktor lain yang dapat menimbulkan gelombang di laut seperti aktifitas seismik di dasar laut (gempa), letusan gunung api, gerakan kapal, gaya tarik benda angkasa (bulan dan matahari) (Nining, 2002). Gelombang laut dapat juga terjadi di lapisan dalam (pada bidang antara dua lapisan air yang mempunyai densitas berbeda). Gelombang ini disebut gelombang dalam (internal waves). Rekaman data gelombang bentuknya sangat rumit, karena itu untuk mempelajari gelombang laut, bentuknya disederhanakan seperti Gambar 1.

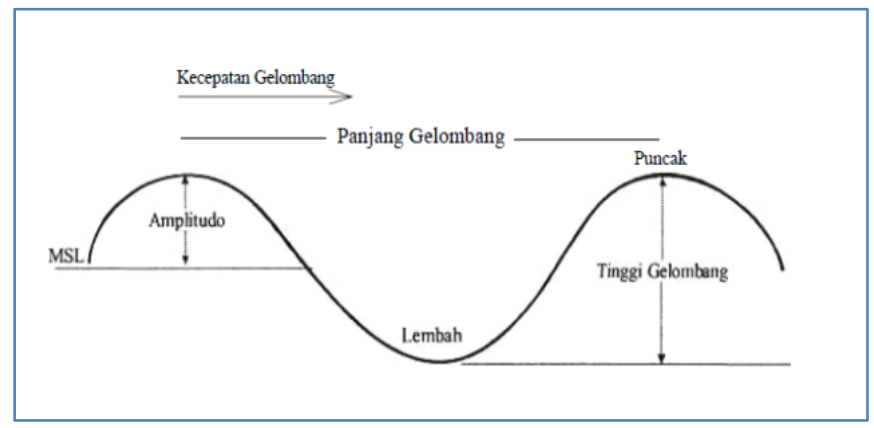

Gambar 1. Gelombang laut yang sederhana. Figure 1. Simple ocean waves

Berdasarkan perbandingan antara kedalaman perairan (d) dan panjang gelombang (L), gelombang laut dapat diklasifikasikan (Nining, 2002) menjadi:

1. Gelombang perairan dalam (Deep water waves) dimana $\mathrm{d} / \mathrm{L}>1 / 2$

2. Gelombang perairan transisi (Transitional waves) dimana $1 / 20<\mathrm{d} / \mathrm{L}$ $<1 / 2$

3. Gelombang perairan dangkal (Shallow water waves) dimana $\mathrm{d} / \mathrm{L}<1 / 20$

Kecepatan rambat gelombang perairan dalam dapat dihitung dengan rumus $\mathrm{C}_{0}=1,56 \mathrm{~T}(\mathrm{~m} / \mathrm{det})$. Kecepatan rambat gelombang perairan transisi dengan rumus $\mathrm{C}=\mathrm{C}_{0}$ tanh $\mathrm{kd}(\mathrm{m} / \mathrm{d})$ dan kecepatan rambat gelombang perairan dangkal ditentukan dari rumus $\mathrm{Cd}=(\mathrm{g}-\mathrm{d})^{1 / 2}$. Gelombang di perairan dalam yang bergerak memasuki perairan pantai 
mengalami transformasi yakni: kecepatannya berkurang, panjang gelombang menjadi lebih pendek dan tingginya bertambah.

Gelombang laut yang bergerak memasuki perairan pantai mengalami pertambahan tinggi yang membuat keterjalan gelombang bertambah. Selanjutnya kecepatan partikel air pada puncak gelombang mendekati kecepatan gelombang. Bila kecepatan partikel air lebih besar daripada kecepatan gelombang maka gelombang menjadi tidak stabil dan pecah. Kriteria lain adalah gelombang akan pecah bila $\mathrm{H} / \mathrm{d}=0,78$. Pecahnya gelombang umumnya dapat dibagi dalam tiga tipe, yaitu spilling, plunging dan surging (Duxbury et al., 2002). Untuk pantai yang landai umumnya terjadi spilling dan di pantai yang agak curam terjadi plunging sedangkan di pantai yang curam terjadi surging.

Pasang surut atmosfer adalah gerakan atmosfer bumi yang diakibatkan oleh adanya aksi gravitasi dari matahari dan bulan atau benda langit lainnya. Gerakan atmosfer akibat hal ini bisa dideteksi dengan alat barometer yang mencatat perubahan tekanan udara di muka laut. Pasang surut bumi adalah gangguan akibat gaya gravitasi benda langit terhadap bagian bumi padat.

Gaya yang menimbulkan pasut disebut gaya pembangkit pasut yang merupakan resultan gaya sentrifugal dan gaya tarik benda langit (bulan dan matahari). Revolusi bulan mengelilingi bumi menimbulkan gaya sentrifugal yang arahnya menjauhi bulan dan besarnya sama setiap titik di permukaan bumi. Sebaliknya gaya tarik bulan bergantung pada jarak dari titik-titik di permukaan bumi terhadap bulan. Makin dekat jarak tersebut, makin besar gaya tarik bulan. Resultan gaya sentrifugal dan gaya tarik bulan ini menghasilkan gaya pembangkit pasut yang bertanggung jawab terhadap timbulnya pasut di laut.

Umumnya pasut dapat diklasifikasikan dalam 4 tipe, yaitu pasut tunggal murni (diurnal tides), pasut ganda campuran (semi diurnal tides), pasut campuran tunggal (mixed predominantly diurnal tides) dan pasut campuran ganda (mixed predominantly semidiurnal tides). Dalam pasut tunggal murni, terjadi satu kali pasang dan satu kali surut dalam sehari sedangkan pada pasut ganda murni dua kali pasang dan dua kali surut dalam sehari. Pada pasut campuran tunggal, umumnya pasang maupun surut terjadi satu kali sehari; kadang-kadang sekali dalam sehari; kadang-kadang dua kali sehari (pada saat pasang perbani). Pada pasut campuran ganda umumnya pada saat pasang maupun surut terjadi dua kali sehari, kadang-kadang sekali sehari (pada saat pasang perbani).

Penelitian ini bertujuan untuk menentukan aspek hidro-oceanografi di pesisir utara Kabupaten Karawang berupa karakteristik gelombang, pasang surut dan arus. Diharapkan hasil penelitian ini dapat memberikan manfaat bagi pemerintah dalam merencanakan pengembangan pesisir utara kabupaten Karawang.

\section{BAHAN DAN METODE \\ Lokasi dan Waktu Penelitian}

Lokasi penelitian dilakukan di sepanjang pantai kabupaten Karawang pada 3 kecamatan, yaitu kecamatan Cibuaya, kecamatan Cilebar dan kecamatan Cilamaya Kulon sesuai Gambar 2. Daerah ini terletak di utara kabupaten Karawang, merupakan daerah pesisir yang berbatasan langsung dengan laut Jawa. Penelitian dilaksanakan pada bulan September 2017. 


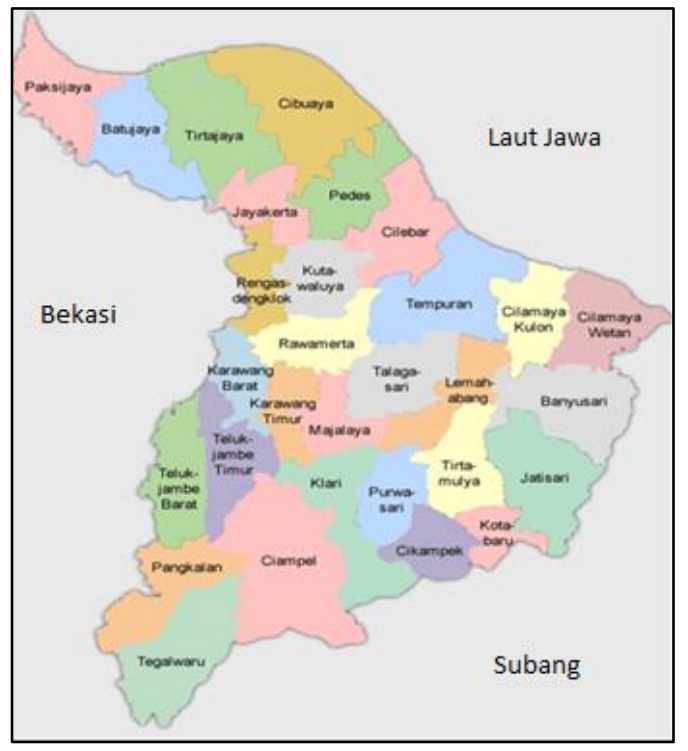

Gambar 2. Lokasi Penelitian, kab. Karawang

Figure 2. Research Site, Karawang district

\section{Alat dan bahan}

Alat yang digunakan adalah alat pengukur arus yang terdiri dari layanglayang arus, dengan bahan dasar seng dan bola pelampung dan alat pengukur gelombang dengan menggunakan tiang skala, stopwatch dan kompas.

\section{Analisa Data}

Pengukuran arus dilakukan dengan menggunakan layang-layang arus, dengan bahan dasar seng dan bola pelampung yang diikatkan pada tali sepanjang 5 (lima) meter. Pengamatan dilakukan dengan melepas layang-layang arus hingga jarak yang telah ditentukan dan mengukur selang waktu yang dibutuhkan. Pengukuran arah pergerakan arus dilakukan dengan membidik searah penjalaran arus dengan menggunakan kompas.

Kecepatan arus diukur menggunakan persamaan:

$$
\mathrm{v}=\mathrm{x} / \mathrm{t}
$$

dimana :

$\mathrm{v}=$ kecepatan arus (m/det)

$\mathrm{x}=$ jarak / panjang tali $(\mathrm{m})$

$\mathrm{t}=$ waktu tempuh (det)
Pengukuran tinggi, periode dan arah gelombang dilakukan dengan menggunakan tiang skala, stopwatch dan kompas. Pengukuran tinggi gelombang dilakukan dengan cara membaca pergerakan naik (puncak) dan turun (lembah) permukaan air laut pada tiang berskala yang ditancapkan di laut. Pengukuran perioda gelombang dilakukan dengan menggunakan stopwatch dengan cara menghitung waktu yang diperlukan pada posisi puncak dan lembah gelombang datang. Arah datang gelombang ditentukan dengan membidik gelombang yang datang secara tegak lurus dengan menggunakan kompas.

Data yang diperoleh di lapangan digunakan untuk menghitung tinggi gelombang, periode rata-rata dan panjang gelombang,

- Tinggi gelombang signifikan:

$$
H_{S}=\frac{3}{N} \sum_{i=1}^{N / 3} H i
$$

- Panjang gelombang:

$$
\mathrm{L}=1,56 \times \mathrm{T}^{2}
$$

- Periode gelombang:

$\mathrm{T}=\mathrm{t} / \mathrm{N}$ 
dimana:

Hs : Tinggi Gelombang Signifikan (m)

$\mathrm{T}$ : Periode Gelombang (det)

L : Panjang gelombang (m)

$\mathrm{t}$ : Lama pengamatan gelombang (det)

$\mathrm{N}$ : Jumlah pengamatan gelombang

Dalam menghitung konstantakonstanta pasang surut di suatu perairan, maka data pencatatan pasang surut tiap jam dari data pengukuran Dishidrosal, data tersebut dijadikan dasar dalam menentukan konstanta-konstanta pasang surut dengan Metode Admiralty. Dengan metode ini, sudah ada konstanta-konstanta pengali yang ditetapkan untuk bisa mendapatkan konstanta-konstanta pasang surut.

\section{HASIL DAN BAHASAN \\ HASIL \\ Pengukuran Arus Laut}

Pengukuran arus laut dilapangan dilakukan dengan menggunakan tali sepanjang 5 meter $(\mathrm{x}=5 \mathrm{~m})$ dan dihitung waktu jalarnya dalam detik, kemudian dihitung kecepatan arusnya. Untuk melihat gambaran secara umum pola arus di ketiga lokasi dilakukan proses griding atau interpolasi dengan menggunakan Surfer 7.0 sehingga diperoleh pola arusnya sesuai Gambar 3.

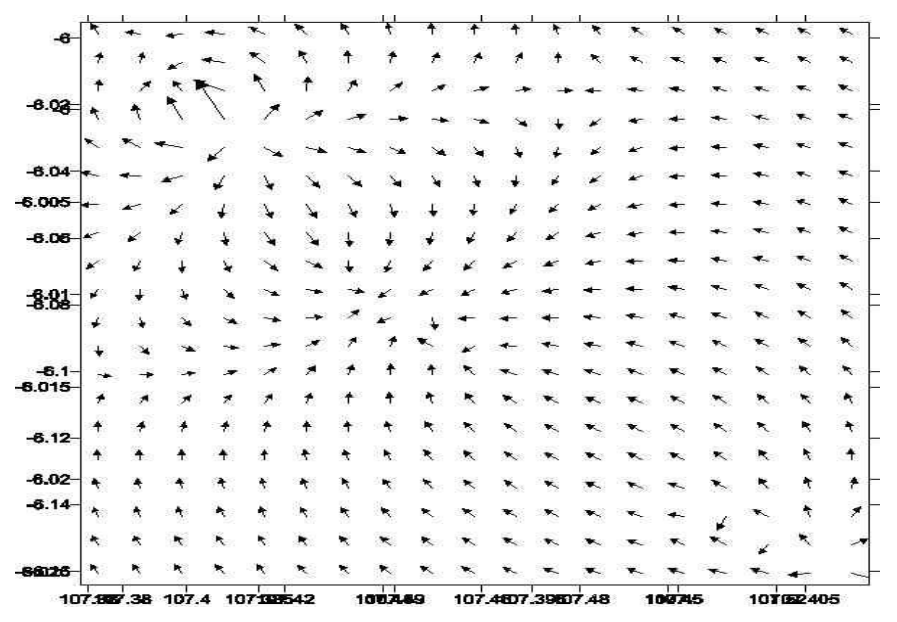

Gambar 3. Pola arus di lokasi penelitian

Figure 3. Current patterns at the research site

Model Arah dan Kecepatan Angin serta Arus Laut

Dari data arah dan kecepatan angin serta arah gelombang, dibuat model arah dan kecepatan angin serta arah dan kecepatan arus laut sesuai Gambar 4, Gambar 5, dan Gambar 6. 

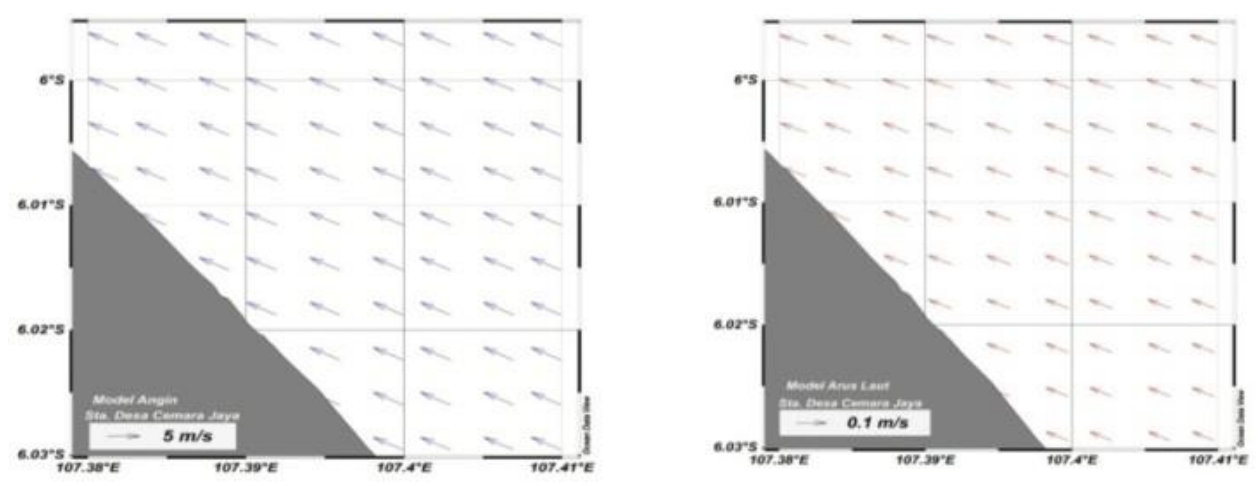

Gambar 4. Model arah angin dan arus di Cibuaya

Figure 4. Models of the sea currents and wind directions at Cibuaya
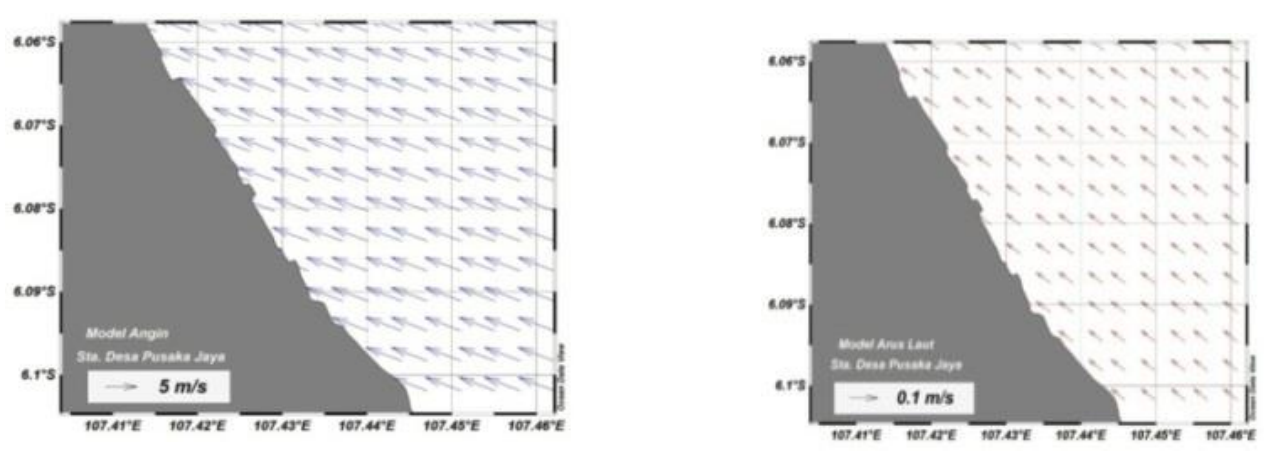

Gambar 5. Model arah angin dan arah arus di Cilebar

Figure 5. Models of the sea currents and wind directions at Cilebar
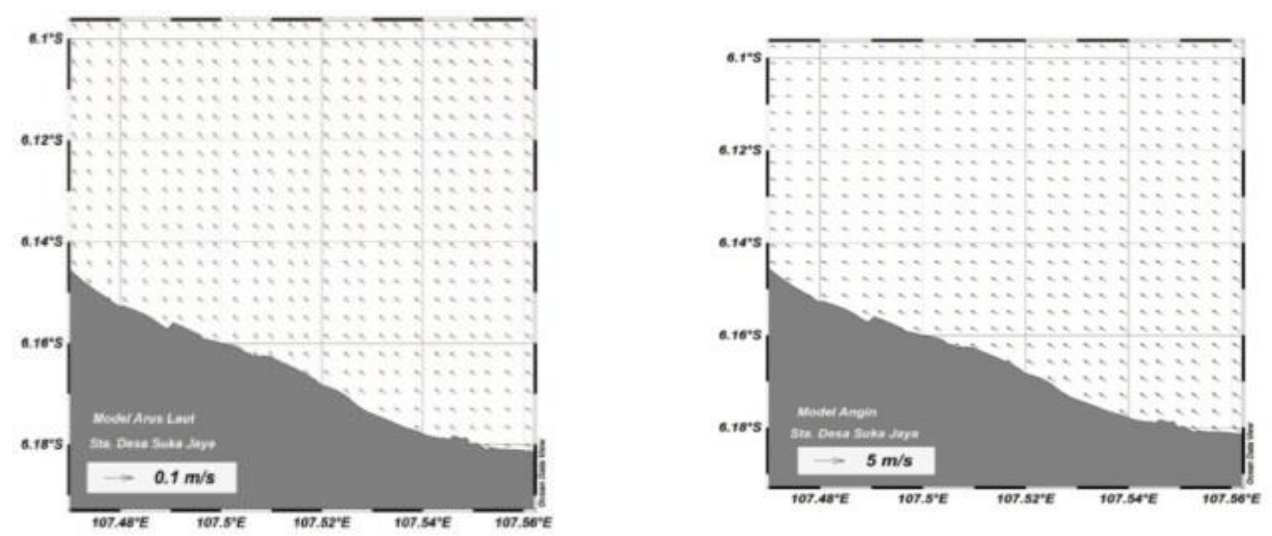

Gambar 6. Model arah angin dan arah arus Cilamaya

Figure 6. Models of the sea currents and wind directions at Cilamaya

\section{Pengukuran Gelombang Laut}

Pengukuran gelombang laut dilapangan dilakukan dengan menggunakan papan pengukur tinggi gelombang di beberapa titik kajian sebagai acuan data untuk perhitungan tinggi dan arah gelombang, hasilnya terlihat pada data terlampir. Dari hasil pengamatan dapat diketahui bahwa tinggi gelombang di desa Cemara Jaya, kecamatan Cibuaya berkisar 2,2 meter yang berarah dominan ke barat 
laut (NW) dengan sudut berkisar $24^{0}$ terhadap garis pantai. Untuk desa Pusaka Jaya, kecamatan Cilebar memiliki tinggi gelombang berkisar 0,634 meter dengan arah dominan ke arah barat (W) dengan sudut datang berkisar $18^{\circ}$. Sedangkan di desa Suka Jaya, kecamatan Cilamaya memiliki tinggi gelombang di pantai berkisar 0,600 meter yang dominan ke arah timur (E) dengan sudut datang $16^{0}$ sesuai yang ditampilkan pada Tabel 1 .

Tabel 1. Tinggi, Periode dan Arah Gelombang

Table 1. High, Period and Wave Directions

\begin{tabular}{clcccc}
\hline No & Lokasi & $\begin{array}{l}\text { Tinggi } \\
\text { Gel (m) }\end{array}$ & $\begin{array}{c}\text { Periode } \\
\text { Gel (m) }\end{array}$ & $\begin{array}{l}\text { Arah } \\
\text { Gel }\end{array}$ & $\begin{array}{l}\text { Sudut } \\
\left({ }^{\circ}\right)\end{array}$ \\
\hline 1 & Cibuaya & 2,2 & $8,0-10,0$ & NW & 24 \\
2 & Cilebar & 0,634 & $6,0-8,0$ & W & 18 \\
3 & Cilamaya & 0,600 & $7,0-9,0$ & E & 16 \\
\hline
\end{tabular}

\section{Pengukuran Pasang Surut}

Pengukuran Pasang Surut dilakukan berdasarkan data yang diperoleh dari Pusat Riset Kelautan Dan Perikanan, BRSDM KP dilakukan pengolahan dengan menggambar grafik pasang surut dan pengolahan data dilakukan dengan menggunakan Metode Admiralty untuk mendapatkan nilai konstanta harmonik pasang surutnya (K1, O1, M2, S2). Konstanta/komponen harmonik pasut ini dipakai untuk penentuan MSL dan tipe pasang surut seperti jumlah pasang dan surut dalam satu hari serta tinggi maksimum dan minimum gelombang laut. Gambar 7 menunjukkan grafik pasang surut di perairan Cemara Jaya, kecamatan Cibuaya memiliki konstanta pasang surut yang diperoleh maka dapat dihitung bilangan Form $=(\mathrm{K} 1$ $+\mathrm{O} 1) /(\mathrm{M} 2+\mathrm{S} 2)=3.9$ dengan bilangan form lebih dari 3 adalah Tipe Pasut Diurnal. Gambar 8 menunjukkan grafik pasang surut di Pusaka Jaya, kecamatan Cilebar memiliki konstanta pasang surut yang diperoleh maka dapat dihitung bilangan Form $=(\mathrm{K} 1+\mathrm{O} 1) /(\mathrm{M} 2+\mathrm{S} 2)=3.87$ dengan bilangan form lebih dari 3 adalah Tipe Pasut Diurnal. Dan, grafik pasang surut di Suka Jaya, kec. Cilamaya Kulon memiliki konstanta pasang surut yang diperoleh maka dapat dihitung Bilangan Form $=(\mathrm{K} 1+\mathrm{O} 1) /(\mathrm{M} 2+\mathrm{S} 2)=3.75$ dengan bilangan form lebih dari 3 adalah Tipe Pasut Diurnal sesuai Gambar 9. 


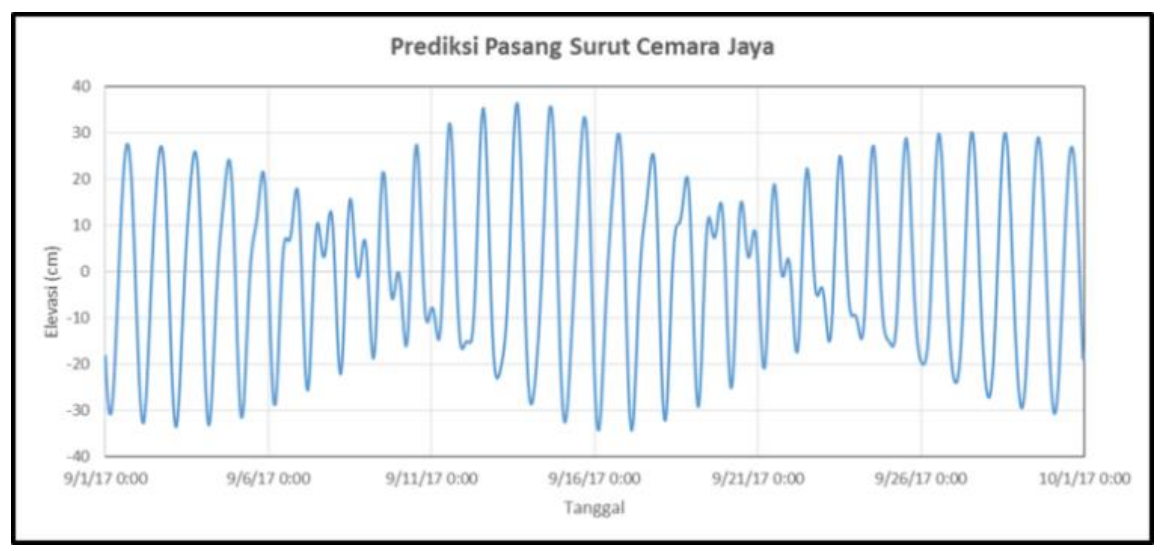

Gambar 7. Grafik Pasang Surut di perairan Cemara Jaya, kecamatan Cibuaya Figure 7. Tidal Grafic at Cemara Jaya Sea

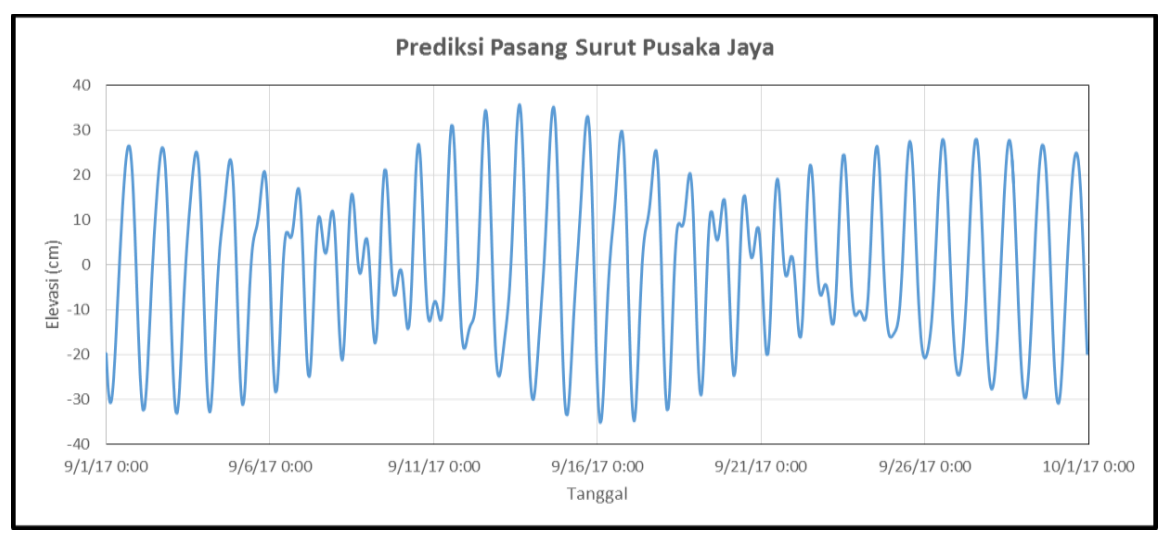

Gambar 8. Grafik Pasang Surut di Pusaka Jaya, kecamatan Cilebar Figure 8. Tidal Grafic at Pusaka Jaya Sea

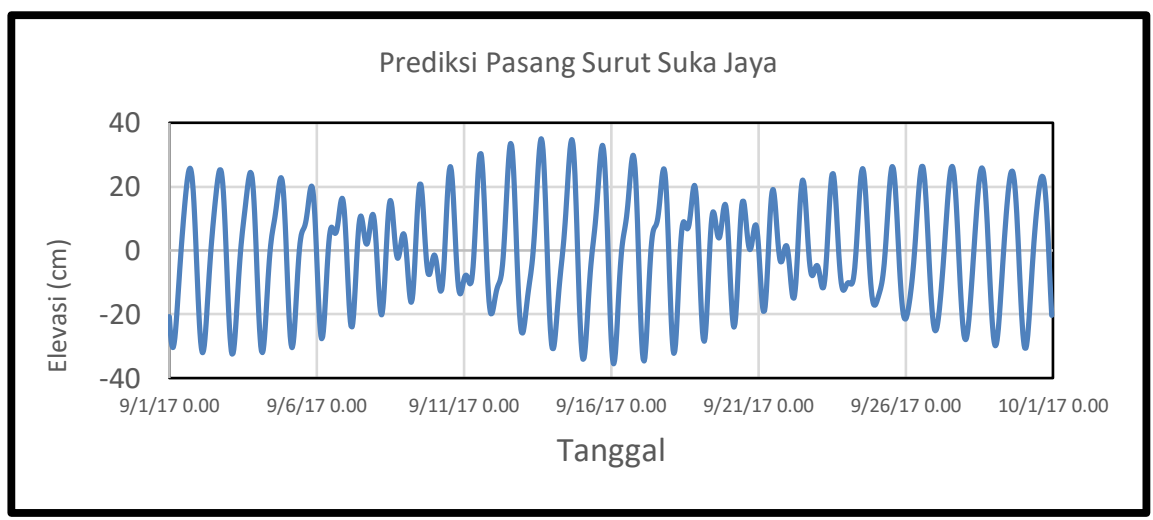

Gambar 9. Grafik Pasang Surut di Suka Jaya, kec. Cilamaya Kulon Figure 9. Tidal Grafic at Suka Jaya Sea

\section{BAHASAN}

Pesisir pantai di kabupaten Karawang semuanya terletak di bagian utara dari wilayah kabupaten Karawang. Wilayah ini terbagi atas beberapa kecamatan seperti, kecamatan Pakisjaya, Batujaya, Cibuaya, Pedes, Cilebar
Tempuran, Cilamaya Kulon dan Cilamaya Wetan. Sebagian besar lahan dimanfaatkan sebagai daerah pemukiman, tambak ikan dan persawahan. Oleh karena aktifitas pemanfaatan lahan di sepanjang pantai tidak terlepas dari pengaruh proses-proses pantai yang berlangsung terus menerus, 
pemanfaatan lahan di daerah pantai sangat rentan terhadap abrasi dan sedimentasi pantai. Menurut Hidayat (2005), kajian hidro-oseanografi pada suatu perairan pantai dapat digunakan untuk memprediksi proses-proses fisik yang terjadi, yaitu kerusakan daerah pantai akibat perubahan garis pantai berupa akresi dan erosi pantai.

Kecamatan Cibuaya memiliki arus laut yang bergerak menuju pantai ke arah barat laut $(\mathrm{NW})$, dengan kecepatan rata rata $0,57 \mathrm{~m} /$ det dan sudut $24^{\circ}$ terhadap pantai. Massa air bergerak dari arah tenggara (SE) ke arah barat laut menyusur sepanjang pantai. Kecamatan Cilebar mencatat arus bergerak menuju pantai ke arah barat daya (SW), dengan kecepatan rata-rata $0,42 \mathrm{~m} /$ det dan sudut $18^{0}$ terhadap pantai. Massa air bergerak dari arah tenggara ke arah barat daya menyusur sepanjang pantai dengan sudut. Sedangkan di kecamatan Cimalaya Kulon, arus bergerak menuju timur laut (NE) dengan kecepatan rata-rata $0,40 \mathrm{~m} / \mathrm{det}$ dan sudut $35^{0}$ terhadap pantai dan meninggalkan pantai. Massa air bergerak dari arah tenggara ke arah barat daya menyusur sepanjang pantai. Pada umumnya arus yang dijumpai pada lokasi penelitian adalah arus pasang surut yang disebabkan oleh naik dan turunnya muka air dan arus susur pantai yang diakibatkan oleh aksi gelombang cukup kecil dengan kisaran 0,125 - 0,167 $\mathrm{m} /$ det. Menurut Lolong \& Masinambow (2011), pantai Inobonto memiliki arah arus dominan Barat Laut dengan kecepatan maksimum rerata arus adalah 0,406 m/det. Kinerja Hidro oceanografi yang sangat mengancam stabilitas pantai Inobonto terjadi disaat bulan basah yaitu antara November sampai April setiap tahun, dimana tinggi gelombang mencapai tinggi maksimum, arus laut mencapai kecepatan maksimum rata-rata. Sementara kecepatan arus di perairan pesisir Lombok Utara berkisar antara $0-0,15 \mathrm{~cm} /$ detik dengan arah arus dominan ke barat daya. Sedangkan pada saat surut kecepatan arus berkisar antara $0-0,32 \mathrm{~cm} /$ detik dengan arah arus dominan menuju Timur Laut (Wisha \& Kusumah, 2019).

Gelombang tertinggi terjadi di kecamatan Cibuaya dengan tinggi $2,4 \mathrm{~m}$, panjang gelombang $45 \mathrm{~m}$ dengan arah datang $45^{\circ}$ dari tenggara (SE) menuju barat laut (NW). Gelombang laut yang bergerak dengan arah datang gelombang dari tenggara terus menjalar mencapai badan pantai tanpa mengalami refleksi karena kurangnya penghalang gelombang. Kecamatan Cilebar memiliki tinggi dan panjang gelombang masing-masing sebesar 2,5 $\mathrm{m}$ dan $35 \mathrm{~m}$ dengan arah datang $47^{\circ}$ dari timur (E) kearah barat laut (NW). Gelombang laut bergerak dengan arah datang gelombang dari timur terus menjalar mencapai badan pantai. Ketika gelombang mencapai pantai menyebabkan pengurangan tinggi gelombang akibat berkurangnya kedalaman perairan, namun tetap cukup tinggi dan berpengaruh terhadap kestabilan pantai di lokasi ini. Gelombang laut di Cilamaya Kulon memiliki ketinggian sebesar $2,2 \mathrm{~m}$ dan panjang sebesar $40 \mathrm{~m}$ dengan arah gelombang $60^{\circ}$ dari barat menuju timur.

Tinggi muka air laut di Pesisir Cibuaya saat pasang tertinggi sebesar 0,632 meter dan saat surut $0,343 \mathrm{~m}$ di bawah mean sea level (MSL) dengan type diurnal yaitu terjadi 1 kali pasang dan 1 kali surut dalam jangka waktu selama satu hari, kondisi ini berbeda dengan jenis pasang surut di perairan Teluk Tahuna yang mengalami pasang surut semi diurnal yaitu terjadi 2 kali pasang surut dalam satu hari (Wuaten et al., 2018). Untuk kecamatan Cilebar air tertinggi pada saat pasang adalah 0,356 meter dan pada saat surut berada pada 0,351 dibawah mean sea level dengan type diurnal yaitu terjadi $1 \mathrm{x}$ pasang dan $1 \mathrm{x}$ surut dalam satu hari. Untuk Cilamaya Kulon muka air tertinggi pada saat pasang adalah 0,350 meter dan saat surut pada 0,355 meter dibawah mean sea level dengan tipe pasutnya adalah diurnal. 


\section{SIMPULAN}

Karakteristik hidro-oseanografi berupa arus, gelombang dan pasang surut yang terjadi di pantai Karawang selama bulan September 2017 adalah sebagai berikut:

1) Kecepatan arus berkisar antara 0,125 $0,167 \mathrm{~m} /$ detik dengan rata-rata kecepatan arus $0,147 \mathrm{~m} /$ detik dan arah arus membentang dari Timur-Barat mengikuti arah angin yang bertiup sesuai musim yang sedang terjadi;

2) Tinggi gelombang adalah antara 2,0-3,0 $\mathrm{m}$ dengan rata rata tinggi gelombang 2,5 $\mathrm{m}$ dan gelombang bergerak dari arah timur menuju Barat; dan

3) Pasang surut yang terjadi rata-rata ketinggian pasang $0,446 \mathrm{~m}$ dan surut $0,349 \mathrm{~m}$ dengan pasang tertinggi 0,632 $\mathrm{m}$ dan surut yang terendah $0,343 \mathrm{~m}$.

\section{DAFTAR PUSTAKA}

Aziz, M. F. (2006). Gerak Air di Laut. Jurnal Oseana, 31(4), 9-21.

Duxbury, A., Alyn, B., Duxbury, C., \& Sverdrup, K. A. (2002). Fundamentals of Oceanography-4 ${ }^{\text {th }} E d$. New York: McGraw-Hill Publishing.
Hidayat, N. (2005). Kajian hidrooseanografi untuk deteksi prosesproses fisik di pantai. Jurnal SMARTek, 3(2), 73-85.

Lolong, M., \& Masinambow, J. (2011). Penentuan karakteristik dan kinerja hidro oceanografi pantai (Study Kasus Pantai Inobonto). Jurnal Ilmiah Media Engineering, 1(2), 127-134.

Nining, S. N. (2002). Oseanografi Fisis. Kumpulan Transparansi Kuliah Oseanografi Fisika, Program Studi Oseanografi, ITB.

Pemerintah Daerah Karawang. (2003). Rencana Detail Tata Ruang Karawang. Karawang: Pemda Karawang.

Wisha, U. J., \& Kusumah, G. (2019). Faktor hidro-oseanografi terhadap distribusi air tawar bersuhu rendah dekat pantai sekitar lokasi keluaran air tanah lepas pantai (KALP) di perairan Lombok Utara, Indonesia. Oseanologi dan Limnologi di Indonesia, 4(3), 145154.

Wuaten, J., Tatontos, Y. V., \& Kumaseh, E. I. (2018). Analisis kondisi hidro oseanografi di perairan Teluk Tahuna kabupaten Kepulauan Sangihe. Jurnal Ilmiah Tindalung, 4(2), 50-52. 
PELAGICUS: Jurnal IPTEK Terapan Perikanan dan Kelautan

Vol.1 No.1: 39-51, Januari 2020

Lampiran 1. Perhitungan Arus Laut di perairan pesisir Cemara Jaya Appendix 1. Determine the Sea Currents at Cemara Jaya Sea

\begin{tabular}{|c|c|c|c|c|c|}
\hline \multirow[t]{2}{*}{$\mathrm{NO}$} & \multicolumn{2}{|l|}{ Koordinat } & \multirow{2}{*}{$\begin{array}{l}\text { Waktu } \\
\mathrm{t}=\operatorname{det} \text { ik }\end{array}$} & \multirow{2}{*}{$\begin{array}{l}\mathrm{Kec} \\
(v=x / t) \mathrm{m} / \mathrm{dt}\end{array}$} & \multirow{2}{*}{$\begin{array}{l}\text { Kecepatan } \\
\text { Rata-rata }\end{array}$} \\
\hline & Lintang & Bujur & & & \\
\hline 1 & -6.025713 & 107.407343 & 8.2 & 0.61 & $0.57 \mathrm{~m} / \mathrm{dt}$ \\
\hline 2 & -6.021885 & 107.404027 & 9.4 & 0.53 & \\
\hline 3 & -6.019221 & 107.402652 & 7.8 & 0.65 & \\
\hline 4 & -6.015635 & 107.399072 & 10.8 & 0.46 & \\
\hline 5 & -6.012522 & 107.395175 & 7.2 & 0.70 & \\
\hline 6 & -6.009418 & 107.391051 & 7.9 & 0.64 & \\
\hline 7 & -6.006119 & 107.387708 & 12 & 0.42 & \\
\hline 8 & -6.002958 & 107.384211 & 8.5 & 0.59 & \\
\hline 9 & -5.999803 & 107.381761 & 9.0 & 0.55 & \\
\hline 10 & -5.995282 & 107.378468 & 8.6 & 0.58 & \\
\hline
\end{tabular}

Lampiran 2. Perhitungan Arus Laut di perairan pesisir Pusaka Jaya Utara Appendix 2. Determine the Sea Currents at North Pusaka Jaya Sea

\begin{tabular}{llllll}
\hline NO & \multicolumn{2}{l}{ Koordinat } & & Waktu & Kec \\
& Lintang & Bujur & $\mathrm{t}=$ detik & Kec \\
$(\mathrm{v}=\mathrm{x} / \mathrm{t})$ & $\mathrm{m} / \mathrm{dtk}$ & Rata-rata \\
\hline 1 & -6.0977 & 107.4571 & 8.12 & 0.62 & $0.42 \mathrm{~m} / \mathrm{dt}$ \\
2 & -6.0952 & 107.4558 & 14.25 & 0.35 & \\
3 & -6.0918 & 107.4531 & 12.82 & 0.39 & \\
4 & -6.0876 & 107.4505 & 11.95 & 0.42 & \\
5 & -6.0844 & 107.4478 & 15.85 & 0.32 & \\
6 & -6.0807 & 107.4437 & 10.82 & 0.46 & \\
7 & -6.0773 & 107.4409 & 11.45 & 0.44 & \\
8 & -6.0733 & 107.4361 & 12.43 & 0.40 & \\
9 & -6.0681 & 107.4321 & 11.27 & 0.44 & \\
10 & -6.0623 & 107.4282 & 11.62 & 0.43 & \\
\hline
\end{tabular}


Lampiran 3. Perhitungan Arus Laut di perairan pesisir Suka Jaya Appendix 3. Determine the Sea Currents at Suka Jaya Sea

\begin{tabular}{llllll}
\hline NO & Koordinat & & Waktu & $\begin{array}{l}\text { Kec } \\
(\mathrm{v}=\mathrm{x} / \mathrm{t})\end{array}$ & $\begin{array}{l}\text { Kec } \\
\mathrm{mata} / \mathrm{data}\end{array}$ \\
& Lintang & Bujur & $\mathrm{t}=$ detik & \\
\hline 1 & -6.16412 & 107.53854 & 11.20 & 0.45 & $0.40 \mathrm{~m} / \mathrm{dt}$ \\
2 & -6.16255 & 107.53487 & 11.67 & 0.43 & \\
3 & -6.16102 & 107.53020 & 11.95 & 0.42 & \\
4 & -6.15915 & 107.52640 & 12.45 & 0.40 & \\
5 & -6.15630 & 107.52263 & 15.62 & 0.32 & \\
6 & -6.15351 & 107.51834 & 13.58 & 0.37 & \\
7 & -6.15010 & 107.51536 & 13.45 & 0.37 & \\
8 & -6.14658 & 107.51153 & 9.88 & 0.51 & \\
9 & -6.14204 & 107.51054 & 11.20 & 0.45 & \\
10 & -6.13885 & 107.50785 & 13.33 & 0.38 & \\
\hline
\end{tabular}

Lampiran 4. Tinggi dan arah gelombang di perairan pesisir Cemara Jaya Appendix 4. High and Direction Wave at Cemara Jaya Sea

\begin{tabular}{|c|c|c|c|c|c|c|c|c|}
\hline \multirow{3}{*}{ Arah } & entase & Kejadic & Terha & ap Ting & ii dan A & ah Gelc & nbang ( & \%) \\
\hline & \multicolumn{8}{|c|}{ Tinggi Gelombang (m) } \\
\hline & Calm & $0.2-0.6$ & $0.6-1.0$ & 1.0-1.4 & $1.4-1.8$ & $1.8-2.2$ & $>2.2$ & Jumlah \\
\hline- & 0.00 & - & - & - & - & - & - & 0.00 \\
\hline Utara & - & 0.00 & 0.00 & 0.00 & o.00 & 0.00 & 0.00 & e.eo \\
\hline Timur Laut & - & 0.00 & 0.00 & 0.00 & 0.00 & 0.00 & 0.00 & อ.e0 \\
\hline Timur & - & o.00 & 0.00 & 0.00 & 0.00 & 0.00 & 7.14 & 7.14 \\
\hline Tenggare & - & 0.00 & 0.00 & 0.00 & 0.00 & o.eo & 0.00 & e.eo \\
\hline Selatan & - & o. 00 & o. 00 & 0.00 & 0. 00 & o.eo & 0.00 & 0.00 \\
\hline Barat Daya & - & o. 00 & o. 00 & 0.00 & o. 00 & o.eo & 0.00 & e. 00 \\
\hline Barat & - & o. 00 & o. 00 & 0.00 & o. 00 & 0.00 & 3.57 & 3.57 \\
\hline Barat Laut & - & o. 00 & 0.00 & 0.00 & 0.00 & อ. 00 & 14.29 & 14.29 \\
\hline Total & - & 0.00 & 0.00 & 0.00 & 0.00 & 0.00 & 25.00 & 25.00 \\
\hline Komulatif & 0.00 & 0.00 & 0.00 & 0.00 & 0.00 & 0.00 & 25.00 & 25.00 \\
\hline
\end{tabular}


PELAGICUS: Jurnal IPTEK Terapan Perikanan dan Kelautan

Vol.1 No.1: 39-51, Januari 2020

Lampiran 5. Tinggi dan arah gelombang di perairan pesisir Pusaka Jaya Appendix 5. High and Direction of Wave at Pusaka Jaya Sea

15 - 21 September 2017

Lokasi : Stasiun Desa Pusaka Jaya

\begin{tabular}{|l|c|c|c|c|c|c|c|c|}
\hline \multicolumn{2}{|c|}{ Prosentase Kejadian Terhadap Tinggi dan Arah Gelombang (\%) } \\
\hline \multirow{2}{*}{ Arah } & \multicolumn{7}{|c|}{ Tinggi Gelombang (m) } \\
\cline { 2 - 9 } & Calm & $0.2-0.6$ & $0.6-1.0$ & $1.0-1.4$ & $1.4-1.8$ & $1.8-2.2$ & 2.2 .2 & Jumlah \\
\hline Utara & 0.00 & - & - & - & - & - & - & 0.00 \\
Timur Laut & - & 0.00 & 0.00 & 0.00 & 0.00 & 0.00 & 0.00 & 0.00 \\
Timur & - & 0.00 & 0.00 & 0.00 & 0.00 & 0.00 & 0.00 & 0.00 \\
Tenggara & - & 0.00 & 0.00 & 0.00 & 0.00 & 0.00 & 3.57 & 3.57 \\
Selatan & - & 0.00 & 0.00 & 0.00 & 0.00 & 0.00 & 0.00 & 0.00 \\
Barat Daya & - & 0.00 & 0.00 & 0.00 & 0.00 & 0.00 & 0.00 & 0.00 \\
Barat & - & 0.00 & 0.00 & 0.00 & 0.00 & 0.00 & 0.00 & 0.00 \\
Barat Laut & - & 0.00 & 0.00 & 0.00 & 0.00 & 0.00 & 28.57 & 28.57 \\
\hline Total & - & 0.00 & 0.00 & 0.00 & 0.00 & 0.00 & 21.43 & 21.43 \\
\hline Komulatif & 0.00 & 0.00 & 0.00 & 0.00 & 0.00 & 0.00 & 53.57 & 53.57 \\
\hline
\end{tabular}

Lampiran 6. Tinggi dan arah gelombang desa Suka Jaya

Appendix 6. High and Direction of Wave at Suka Jaya Sea

24 - 30 September 2017

Lokasi : Stasiun Desa Suka Jaya

\begin{tabular}{|l|c|c|c|c|c|c|c|c|}
\hline \multicolumn{7}{|c|}{ Prosentase Kejadian Terhadap Tinggi dan Arah Gelombang (\%) } \\
\hline \multirow{2}{*}{ Arah } & \multicolumn{7}{|c|}{ Tinggi Gelombang (m) } \\
\cline { 2 - 9 } & Calm & $0.2-0.6$ & $0.6-1.0$ & $1.0-1.4$ & $1.4-1.8$ & $1.8-2.2$ & 2.2 & Jumlah \\
\hline Utara & 0.00 & - & - & - & - & - & - & 0.00 \\
Timur Laut & - & 0.00 & 0.00 & 0.00 & 0.00 & 0.00 & 3.57 & 3.57 \\
Timur & - & 0.00 & 0.00 & 0.00 & 0.00 & 0.00 & 10.71 & 10.71 \\
Tenggara & - & 0.00 & 0.00 & 0.00 & 0.00 & 0.00 & 17.86 & 17.86 \\
Selatan & - & 0.00 & 0.00 & 0.00 & 0.00 & 0.00 & 0.00 & 0.00 \\
Barat Daya & - & 0.00 & 0.00 & 0.00 & 0.00 & 0.00 & 0.00 & 0.00 \\
Barat & - & 0.00 & 0.00 & 0.00 & 0.00 & 0.00 & 0.00 & 0.00 \\
Barat Laut & - & 0.00 & 0.00 & 0.00 & 0.00 & 0.00 & 10.71 & 10.71 \\
\hline Total & - & 0.00 & 0.00 & 0.00 & 0.00 & 0.00 & 50.00 & 50.00 \\
\hline Komulatif & 0.00 & 0.00 & 0.00 & 0.00 & 0.00 & 0.00 & 50.00 & 50.00 \\
\hline
\end{tabular}

